\title{
Changes in Quality Characteristics of Fresh Pork Patties Added with Tomato Powder during Storage
}

\author{
Suk-Nam Kang, Sang-Keun Jin, Mira Yang, and II-Suk Kim* \\ Department of Animal Resources Technology, Department of Food Science, \\ Jinju National University, Jinju 660-758, Korea
}

\begin{abstract}
This study was carried out to determine the effects of olive oil prepared tomato powder (OPTP) used as lycopene source on fresh pork patties. OPTP was not added $(0 \%$; $)$, or was added at $0.25 \%(\mathrm{~T} 1), 0.5 \%(\mathrm{~T} 2), 0.75 \%(\mathrm{~T} 3)$ and $1.0 \%(\mathrm{~T} 4)$ in a basic pork patty formula and patties were stored for 7 days at $5^{\circ} \mathrm{C}$. $\mathrm{pH}$ values of T3 and T4 were lower $(p<0.05)$ than those of control until storage day 3. However, $\mathrm{pH}$ values of treated samples were dramatically increased $(p<0.05)$ after $7 \mathrm{~d}$ of storage. Cooking loss values of treatments were lower $(p<0.05)$ than those of control at day 1 of storage. Thiobarbituric acid reacting substances values were lower $(p<0.05)$ in all treatments than in untreated samples during storage. All treated samples had lower values $(p<0.05)$ for lightness $\left(\mathrm{L}^{*}\right)$ but significantly higher values $(p<0.05)$ for redness $\left(\mathrm{a}^{*}\right)$ and yellowness $\left(\mathrm{b}^{*}\right)$ than the untreated samples during storage. Total plate counts of T4 were lower $(p<0.05)$ than others during storage. In sensory evaluation, the scores of color, aroma and overall acceptability in T3 and T4 scored higher $(p<0.05)$ than those of control at days 1 and 3 of storage, however, statistical significance was not found $(p>0.05)$ among the samples after 7 days of storage. In conclusion, tomato powder-treated groups were significantly higher in redness $\left(a^{*}\right)$ and yellowness $\left(b^{*}\right)$, and lipid oxidation was inhibited, as compared with control during storage. Therefore, as a natural additive, tomato powder could be used to extend the self-life of meat products, providing the consumer with food containing natural additives, which might be seen more healthful than those of synthetic origin.
\end{abstract}

Key words: tomato powder, lycopene, non-cooked pork patty, meat quality

\section{Introduction}

In these days consumers have demanded meat products that are safe, nutritious, convenient, rich in variety, attractive (in appearance, texture, odor, and taste) and innovative. The consumer preference for naturally derived colorants is associated with their image of being healthy and of good quality. In addition, some synthetic colorants are considered to be responsible for allergenic and intolerance reactions (Østerlie and Lerfall, 2005). This stimulates interest in manufacturing meat products by using new technologies and formulations, using different types of meat and reducing levels of sodium or potassium nitrite, phosphate, salt and fat, all of which lead to beneficial effects on health (Arun et al., 2010; Lin and Lin, 2002).

Tomatoes are an integral part of the human diet world-

*Corresponding author: Il-Suk Kim, Dept. of Animal Resources Technology, Jinju National University, Jinju 660-758, Korea. Tel: 82-751-3512. E-mail: iskim@jinju.ac.kr wide. Although they are frequently consumed fresh, over $80 \%$ of tomato consumption comes from processed products such as tomato juice, paste, pure, ketchup and sauce (Gould, 1992). Recent studies have indicated the potential health benefits of a diet rich in tomatoes and tomato products (Tapiero et al., 2004). Tomato and tomato products are the major sources of lycopene and are considered to be important contributors of carotenoids in human diet (Goula and Adamopoulos, 2005; Tapiero et al., 2004). Tomato and tomato products are rich in lycopene and other carotenoids such as $\beta$-carotene, phytoene, phytofluene and lutein (Choski and Joshi, 2007; Kavanaugh et al., 2007). The ability of lycopene to act as a potent antioxidant is thought to be responsible for protecting cells against oxidative damage and thereby decreasing the risk of chronic diseases (Kavanaugh et al., 2007; Omoni and Aluko, 2005). Adding tomato, tomato products or lycopene to meat could lead to products with health benefits. However, few studies have been reported regarding the use of tomato products or lycopene in meat and meat products (Candogan, 2002; Deda et al., 2007; Østerlie 
and Lerfall, 2005; Sánchez-Escalante et al., 2003; Yilmaz et al., 2002). The present study addresses the utilization of different level of tomato powder as antioxidant treatments in fresh pork patties. Our objective was to evaluate the effectiveness of different levels of tomato powder for inhibiting lipid oxidation and color stability as well as microbial growth in fresh pork patties packaged with oxygen-permeable bag during refrigerated storage at $5^{\circ} \mathrm{C}$ for $7 \mathrm{~d}$.

\section{Materials and Methods}

\section{Preparation of dried tomato powder}

Fresh tomato harvested in August 2007 was obtained from an agricultural products wholesale market in Jinju, Korea. After washing and dicing, hot-air drying method was used. Tomato paste $(5 \mathrm{~kg})$ was mixed with olive oil $(140 \mathrm{~mL})$, and dried at $80^{\circ} \mathrm{C}$ for $2 \mathrm{~h}$ and $60^{\circ} \mathrm{C}$ for $72 \mathrm{~h}$ using a hot-air drying oven (DMC-122SP, Daeil Eng. Co., Korea) to $3-5 \%$ moisture content. The dried tomato was then pulverized using a blender (3030, Hsign Feng Enterprise Factory, Taiwan) and sieved through a No. 40 stainless sieve (40 mesh). The resulting tomato powder prepared with olive oil (TPPO) were then sealed and kept at $-40^{\circ} \mathrm{C}$. The powder prepared by this way had color values in lightness (CIE L*) 46.24, redness (CIE a*) 8.26 and yellowness (CIE b*) 6.26 .

\section{Meat patty manufacture}

Fresh pork loin and backfat were obtained from a local meat market. Fresh pork meats were trimmed of separable fat to provide very lean meats. The lean meat and the pork backfat were separately ground through a $10 \mathrm{~mm}$ plate and then through a $5 \mathrm{~mm}$ plate. Ground meat was thoroughly mixed with salt, seasoning, ice and ground back fat using a mixer (5K5SS, KitchenAid $\AA$, USA). Used seasonings and additives were obtained from MSC Co., Ltd. (Seongnam, Korea). Pork meat patties were formulated according to the experimental design with a base formula containing ground pork, ground fat, salt, pepper, ice as well as four levels of TPPO [0\% (C), 0.25\% (T1), $0.25 \%$ (T2), $0.5 \%$ (T3) and $0.75 \%$ (T4)] (Table 1). The selected adding concentrations of TPPO were decided mainly by preliminary experiments of sensory evaluation. All treatments, about $5 \mathrm{~kg}$ each, were replicated three times from separate meat sources at three different time periods. Pork meat patties were hand linked at $2 \mathrm{~cm}$ thickness, and weighed approximate $50 \mathrm{~g}$. The fresh pork patties were packed with a thin polyethylene film of high
Table 1. Formula of fresh pork patties added with different levels (\%) of TPPO ${ }^{1)}$

\begin{tabular}{lrrrrr}
\hline \hline \multirow{2}{*}{ Ingredients } & \multicolumn{5}{c}{ Treatments } \\
\cline { 2 - 6 } & \multicolumn{1}{c}{$\mathrm{C}$} & \multicolumn{1}{c}{$\mathrm{T} 1$} & $\mathrm{~T} 2$ & \multicolumn{1}{c}{$\mathrm{T} 3$} & $\mathrm{~T} 4$ \\
\hline Pork loin & 80.0 & 80.0 & 80.0 & 80.0 & 80.0 \\
Pork Fat & 10.0 & 10.0 & 10.0 & 10.0 & 10.0 \\
$\mathrm{NaCl}$ & 1.2 & 1.2 & 1.2 & 1.2 & 1.2 \\
$\mathrm{~B}-$ pepper & 0.3 & 0.3 & 0.3 & 0.3 & 0.3 \\
Ice/wate & 8.5 & 8.5 & 8.5 & 8.5 & 8.5 \\
TPPO & 0.00 & 0.25 & 0.50 & 0.75 & 1.00 \\
\hline 1) TPPO: tomato powder prepared with olive oil.
\end{tabular}

oxygen permeability (equal to aerobic package) and were stored in the dark room at $5^{\circ} \mathrm{C}\left( \pm 1^{\circ} \mathrm{C}\right)$ until subsequent analysis.

\section{pH value}

The $\mathrm{pH}$ values were measured by blending $10 \mathrm{~g}$ of samples with $90 \mathrm{~mL}$ distilled water for $30 \mathrm{~s}$ (T25B, IKA, Malaysia). Readings were taken with a $\mathrm{pH}$ meter (8603, Metrohm, Switzerland).

\section{Cooking loss}

The packages were heated in a water bath at $75^{\circ} \mathrm{C}$ for 1 $\mathrm{h}$ and then cooled at room temperature for $30 \mathrm{~min}$. The cooking-loss percentage was determined by the sample weight differences between before and after cooking.

\section{TBARS}

The 2-thiobarbituric acid reactive substances (TBARS) test according to Tarladgis et al. (1960) was used to determine the extent of oxidative rancidity. A $5 \mathrm{~g}$ sample was homogenized in a $50 \mathrm{~mL}$ centrifuge tube with a $50 \mathrm{uL}$ of BHA (7.2\% in ethanol) and $15 \mathrm{~mL}$ of distilled water by using a homogenizer (T-25B, IKA, Malaysia). Two $\mathrm{mL}$ of the homogenate was mixed with $4 \mathrm{~mL}$ of a thiobarbituric acid (TBA/trichloroacetic acid (TCA) solution (20 mM TBA in $15 \%$ TCA), heated at $90^{\circ} \mathrm{C}$ in water bath. After heating the samples were cooled in ice and centrifuged for $15 \mathrm{~min}$ at 2,000 rpm by using a centrifuge (UNION 5KR, Hanil Science Industrial, Korea). The absorbance of the supernant was measured at $532 \mathrm{~nm}$ by using a spectrophotometer (Spectronic Genesys 5, Thermo Fisher Scentific, USA). The concentration (mg MA (malonaldehyde))/ $\mathrm{kg}$ sample on the basis of wet weight) was calculated using a standard curve.

Volatile basic nitrogen (VBN) values

A micro-diffusion method described by Pearson (1968) 
was modified for the determination of VBN. One $10 \mathrm{~g}$ homogenized sample was mixed with $90 \mathrm{~mL}$ distilled water and blended for 30 seconds at low speed (T25Basic, IKA, Malaysia). The prepared mixture was filtered (Whatman No. 2 filter paper). One milliliter of filtrate was pipetted to the Conway dish containing $1 \mathrm{~mL}$ saturated $\mathrm{K}_{2} \mathrm{CO}_{3}$ solution and allowed for reaction at $37^{\circ} \mathrm{C}$ for $120 \mathrm{~min}$. Boric acid solution containing indicator (methyl red and bromocresol green) was used to absorb volatile nitrogen. The solution was titrated with $0.01 \mathrm{~N} \mathrm{HCl}$ and VBN value was expressed as mg VBN/ $100 \mathrm{~g}$ of the sample.

\section{Color measurement}

Color was measured instrumentally using a spectrocolorimeter (CR 400, Minolta Co., Japan) $(\lambda: 400-700 \mathrm{~nm}$, $\left.\Delta \lambda: 10 \mathrm{~nm}, \mathrm{D} 65,10^{\circ}\right)$ calibrated with a white plate and light trap supplied by the manufacturer. Color was expressed using the CIE L ${ }^{*}{ }^{*} b^{*}$ color system (CIE, 1976). The instrument was standardized each time with a white ceramic plate $\left(\mathrm{L}_{0}=89.2, \mathrm{a}_{0}=0.921\right.$, and $\left.\mathrm{b}_{0}=0.783\right)$. The three fundamental color coordinates are CIE L*, $\mathrm{a}^{*}$ and $\mathrm{b}^{*}$. The CIE L* measures the lightness and is a measure of the light reflected $(100=$ white; $0=$ black $)$; CIE a ${ }^{*}$ measures positive red, negative green and CIE $b^{*}$ measures positive yellow, negative blue (CIE, 1976).

\section{Total plate count (TPC)}

Two duplicate $25 \mathrm{~g}$ samples were taken aseptically from each treatment, transferred to sterile plastic pouches and homogenized for $2 \mathrm{~min}$ at room temperature with 225 $\mathrm{mL}$ sterile $0.88 \%(\mathrm{w} / \mathrm{v})$ ringer solution using a stomacher Lab-Blender (78860 ST-Nom, Interscience, France). Appropriate dilutions of samples were prepared in $0.88 \%$ Ringer solution blank and plated in duplicates onto plate count agar (PCA, Difco Lab, USA) for total bacteria and incubated at $32^{\circ} \mathrm{C}$ for $48 \mathrm{~h}$ under anaerobic conditions.

\section{Sensory evaluation}

The samples were served to 12 experienced panel members. Panelists were presented with randomly coded samples. The color, aroma $(1=$ extremely undesirable, 9 $=$ extremely desirable), juiciness $(1=$ extremely dry, $9=$ extremely juicy) and overall acceptability $(1=$ extremely undesirable, 9 = extremely desirable) of the samples were evaluated using 9-point descriptive scale. Panelists were required to cleanse their palate between samples with water.

\section{Statistical analysis}

An analysis of variance were performed on all the variables measured using the general linear model (GLM) procedure of the SAS statistical package (SAS Institute, 1999). The Duncan's multiple range test $(p<0.05)$ was used to determine differences between treatment means.

\section{Results and Discussion}

\section{pH value}

Table 2 shows the results for $\mathrm{pH}$ values of fresh pork patties added with TPPO during storage. The addition with $0.5 \%, 0.75 \%$ and $1.0 \%$ TPPO had lower $(p<0.05)$ $\mathrm{pH}$ values in fresh pork patties than the control on day 1 and 3 of storage. A decrease in the $\mathrm{pH}$ value of meat products containing tomato paste have been reported by Candogan (2002), Hoe et al. (2006) and Deda et al. (2007). Similar results have been reported by Yilmaz et al. (2002) for Turkish sausages produced with tomato juice. This is due to the low $\mathrm{pH}$ value of tomato powder (pH 3.48). After 7 days of storage, the $\mathrm{pH}$ values of $\mathrm{T} 1$, $\mathrm{T} 2$, T3 and $\mathrm{T} 4$ samples dramatically increased by 0.07 , $0.06,0.15$ and 0.20 unit of initial $\mathrm{pH}$ values, respectively. The increments of $\mathrm{pH}$ in treated samples were significant at $p<0.05$ and was somewhat more intensive than that the control under the same conditions. In agreement with findings by other authors, $\mathrm{pH}$ values higher than 5.8 favored microbial growth (Drosinos and Board, 1995;

Table 2. Changes in $\mathbf{p H}$ and cooking loss value of fresh pork patties added with TPPO during storage at $5^{\circ} \mathrm{C}$

\begin{tabular}{|c|c|c|c|c|c|}
\hline & \multirow{2}{*}{ Treatments $^{1)}$} & \multicolumn{4}{|c|}{ Storage days } \\
\hline & & 1 & 3 & 7 & $\mathrm{SEM}^{2)}$ \\
\hline \multirow{6}{*}{$\mathrm{pH}$} & $\mathrm{C}$ & $5.52^{\mathrm{a}}$ & $5.53^{\mathrm{a}}$ & $5.54^{\mathrm{e}}$ & 0.01 \\
\hline & $\mathrm{T} 1$ & $5.52^{\mathrm{Ba}}$ & $5.50^{\mathrm{Ba}}$ & $5.59^{\mathrm{Ac}}$ & 0.01 \\
\hline & $\mathrm{T} 2$ & $5.50^{\mathrm{Bb}}$ & $5.49^{\mathrm{Bb}}$ & $5.56^{\mathrm{Ad}}$ & 0.01 \\
\hline & $\mathrm{T} 3$ & $5.48^{\mathrm{Bc}}$ & $5.48^{\mathrm{Bb}}$ & $5.63^{\mathrm{Ab}}$ & 0.03 \\
\hline & $\mathrm{T} 4$ & $5.46^{\mathrm{Bd}}$ & $5.46^{\mathrm{Bb}}$ & $5.66^{\mathrm{Aa}}$ & 0.03 \\
\hline & $\mathrm{SEM}^{2)}$ & 0.01 & 0.01 & 0.01 & \\
\hline \multirow{6}{*}{$\begin{array}{c}\text { Cooking } \\
\text { loss }\end{array}$} & $\mathrm{C}$ & $9.55^{\mathrm{Ca}}$ & $11.67^{\mathrm{B}}$ & $13.66^{\mathrm{A}}$ & 0.66 \\
\hline & $\mathrm{T} 1$ & $9.33^{\mathrm{Cab}}$ & $11.30^{\mathrm{B}}$ & $14.07^{\mathrm{A}}$ & 0.84 \\
\hline & $\mathrm{T} 2$ & $9.12^{\mathrm{Cab}}$ & $11.78^{\mathrm{B}}$ & $13.34^{\mathrm{A}}$ & 0.62 \\
\hline & $\mathrm{T} 3$ & $9.17^{\mathrm{Cab}}$ & $11.36^{\mathrm{B}}$ & $14.21^{\mathrm{A}}$ & 0.69 \\
\hline & $\mathrm{T} 4$ & $8.36^{\mathrm{Bb}}$ & $13.32^{\mathrm{AB}}$ & $14.34^{\mathrm{A}}$ & 1.10 \\
\hline & $\mathrm{SEM}^{2)}$ & 0.16 & 0.47 & 0.16 & \\
\hline
\end{tabular}

\footnotetext{
${ }^{1)}$ Treatments are the same as described in Table 1.

${ }^{2)}$ Pooled standard errors of the mean.

${ }^{\mathrm{a}-\mathrm{e}}$ Means with different superscripts in the same column significant differences at $p<0.05$.

${ }^{\mathrm{A}-\mathrm{C}}$ Means with different superscripts in the same row significant different at $p<0.05$.
} 
Kennedy et al., 2005; Vergara and Gallego, 2001), however, our results showed that higher $\mathrm{pH}$ values of $\mathrm{T} 3$ and $\mathrm{T} 4$ samples (5.63 and 5.66, respectively) resulted in lower total plate counts (5.68 and $5.77 \log \mathrm{CFU} / \mathrm{g}$ ) compared to the control (TPC $6.98 \mathrm{log} \mathrm{CFU} / \mathrm{g}$ ) of non-cooked pork meat patties on day 7 of storage (Table 2).

\section{Cooking loss}

Table 2 shows the results for cooking loss values of fresh pork patties added with TPPO during storage. The high addition of TPPO group (T4) significantly decreased $(p<0.05)$ the cooking loss on day 1 of storage. Among the treatments, cooking loss of $\mathrm{T} 4$ had the lowest values on day 1 of storage. However, on day 3 and 7 of storage, no differences $(p>0.05)$ in cooking loss were found among the samples. Storage time increased $(p<0.05)$ the cooking loss in all treatments. Razminowicz et al. (2006) determined cooking loss to estimate water-holding capacity (WHC) of meat. WHC is a factor that determines the juiciness of meat and is defined as the ability of meat to retain its water during application of external forces, such as cutting, heating, grinding or pressing (Zhang et al., 2005). According to our results, these low levels of adding tomato powder in fresh pork patties may not affect cooking loss.

\section{Lipid oxidation}

Table 3 shows the results for TBARS values of fresh pork patties added with TPPO during storage. In fresh pork patties containing TPPO significantly lower of TBARS values compared to control were observed. The higher concentration of TPPO in pork patties, the lower $(p<0.05)$ TBARS values were shown. Candogan (2002) who found that in beef patties, produced without the use of sodium nitrite, the treatments added with $5 \%, 10 \%$ and $15 \%$ tomato paste had lower $(p<0.05)$ TBA values than the control, due to the antioxidative activity of lycopene present in tomato paste. TBA value of all fresh pork patties increased during storage $(p<0.05)$.

In general, the effect of a certain lipid oxidation might vary considerably depending on a complex interaction between various factors, involving the type and concentration of active compound(s) and the nature of the food system (Madsen and Bertelsen, 1995; Schwarz et al., 2001). The addition of $\mathrm{NaCl}$ at $0.5-2.5 \%$ was claimed to be prooxidative and therefore to promote lipid oxidation (Rhee and Ziprin, 2001). Dzudie et al. (2004) reported that the TBA values of pork fat were higher than those of beef fat in beef patties during storage. In this study,
Table 3. Changes in TBARS and VBN value and total plate counts (TPC) (log CFU/g) of fresh pork patties added with TPPO during storage at $5^{\circ} \mathrm{C}$

\begin{tabular}{cclllc}
\hline \hline & & \multicolumn{4}{c}{ Storage days } \\
\cline { 3 - 6 } & & \multicolumn{1}{c}{1} & \multicolumn{1}{c}{3} & \multicolumn{1}{c}{7} & SEM $^{2}$ \\
\hline & $\mathrm{C}$ & $0.44^{\mathrm{Ba}}$ & $0.50^{\mathrm{Ba}}$ & $0.74^{\mathrm{Aa}}$ & 0.04 \\
TBARS & $\mathrm{T} 1$ & $0.32^{\mathrm{Cb}}$ & $0.37^{\mathrm{Bb}}$ & $0.58^{\mathrm{Ab}}$ & 0.05 \\
$(\mathrm{mg} \mathrm{MA} / \mathrm{kg})$ & $\mathrm{T} 2$ & $0.29^{\mathrm{Bbc}}$ & $0.31^{\mathrm{Bbc}}$ & $0.50^{\mathrm{Ac}}$ & 0.03 \\
& $\mathrm{~T} 3$ & $0.26^{\mathrm{Bc}}$ & $0.26^{\mathrm{Bc}}$ & $0.43^{\mathrm{Acd}}$ & 0.28 \\
& $\mathrm{~T} 4$ & $0.25^{\mathrm{Bc}}$ & $0.25^{\mathrm{Bc}}$ & $0.42^{\mathrm{Ad}}$ & 0.03 \\
& $\mathrm{SEM}^{2)}$ & 0.02 & 0.03 & 0.03 & \\
\hline & $\mathrm{C}$ & 3.40 & 4.39 & 4.54 & 0.27 \\
VBN & $\mathrm{T} 1$ & 4.08 & 4.39 & 4.94 & 0.36 \\
& $\mathrm{~T} 2$ & 4.04 & 4.55 & 5.33 & 0.37 \\
& $\mathrm{~T} 3$ & 3.55 & 4.11 & 4.78 & 0.34 \\
& $\mathrm{~T} 4$ & 4.23 & 4.97 & 5.49 & 0.32 \\
& $\mathrm{SEM}{ }^{2)}$ & 0.28 & 0.20 & 0.28 & \\
\hline TPC & $\mathrm{C}$ & $4.05^{\mathrm{Ca}}$ & $5.89^{\mathrm{Ba}}$ & $6.98^{\mathrm{Aa}}$ & 0.43 \\
& $\mathrm{~T} 1$ & $4.13^{\mathrm{Ba}}$ & $5.75^{\mathrm{Aab}}$ & $6.65^{\mathrm{Aa}}$ & 0.29 \\
$(\log$ CFU/g) & $\mathrm{T} 2$ & $4.14^{\mathrm{Ca}}$ & $5.79^{\mathrm{Aab}}$ & $5.98^{\mathrm{Bb}}$ & 0.25 \\
& $\mathrm{~T} 3$ & $4.12^{\mathrm{Ca}}$ & $5.52^{\mathrm{Bb}}$ & $5.68^{\mathrm{Ac}}$ & 0.36 \\
& $\mathrm{~T} 4$ & $3.11^{\mathrm{Cb}}$ & $4.87^{\mathrm{Bc}}$ & $5.77^{\mathrm{Ac}}$ & 0.65 \\
& $\mathrm{SEM}{ }^{2)}$ & 0.21 & 0.10 & 0.15 &
\end{tabular}

${ }^{1)}$ Treatments are the same as described in Table 1.

${ }^{2)}$ Pooled standard errors of the mean.

${ }^{\text {a-d }}$ Means with different superscripts in the same column significant differences at $p<0.05$.

${ }^{\mathrm{A}, \mathrm{B}}$ Means with different superscripts in the same row significant differences at $p<0.05$.

increased TBARS values were significantly decreased with adding TPPO at the initial time of storage. At day 7 of storage, TBARS value of $\mathrm{C}, \mathrm{T} 1, \mathrm{~T} 2, \mathrm{~T} 3$ and $\mathrm{T} 4$ was $0.74,0.58,0.50,0.43$ and $0.42 \mathrm{mg}$ malonaldehyde $/ \mathrm{kg}$, respectively. The TBARS values of TPPO treated samples were significantly lower than the control $(p<0.05)$. However, even after 7 days of storage, the TBARS values in TPPO treated samples remained lower than $0.60 \mathrm{mg}$ malonaldehyde $/ \mathrm{kg}$ and lower than the minimum detectable level in raw ground meat for oxidized flavor by an inexperienced panel (Greene and Cumuze, 1982). The TBARS values in cooked beef between 0.5-1.0 were perceived by trained panelist, which are determined to be the threshold values being characterized as an oxidized flavor (Tarladgis et al., 1960). The TBARS values between 0.62.0 were perceived by inexperienced panelists (Greene and Cummuze, 1982).

\section{VBN values}

VBN is related to protein breakdown (Ahn et al., 2000; Egan et al., 1981), which is associated with the amino acid decarboxylase activity of microorganisms during 
storage and generally could be used as a quality indicator for fish products (Lin et al., 1995; Ohasi et al., 1991). Changes in VBN value during storage are shown in Table 3. The VBN values of tested samples slightly increased, but not significantly increased as expected when storage time increased in fresh pork patties. Results from our studies were not confirmed with the several researchers (Lin et al., 1995 Ohasi et al., 1991), who reported that higher VBN values for meat products were associated with the higher microbial counts among treatments. These disagreed results of fresh pork patties may be due to the incomplete degradation of protein comparing to the cooked samples (Collins and Charles, 1987; Wang, 2000), who suggested that samples that had more antioxidant materials added had significantly lower VBN values $(p<0.05)$. All the samples in this study did not exceed 20 $\mathrm{mg} / 100 \mathrm{~g}$, which is the value that often described as the level of meat spoilage (Su and Lin, 1988).

\section{Total plate count}

TPC of T4 sample was significantly lower than other samples, however, no significant differences among $\mathrm{C}$, $\mathrm{T} 1, \mathrm{~T} 2$, and T3 samples were found on day 1 of storage (Table 3). And on day 3 and 7, the TPCs of treated samples added with TPPO were lower than those of control sample. The TPCs of samples increased steadily during storage, reaching $6.98 \log \mathrm{CFU} / \mathrm{g}$ in control samples after 7 days. And the TPC of treated fresh pork patties pork added with TPPO decreased 0.33, 1.00, 1.30 and 1.21 logs in T1, T2, T3 and T4 samples, respectively, after 7 days compared to control $(p<0.05)$. This confirms the results found by researchers studying the antimicrobial effects of tomato (Yilmaz et al., 2002). These low bacterial counts of treated groups added with TPPO seemed to have antimicrobial materials just like lycopene in tomato powder.

\section{Surface color}

Table 4 shows the results for surface color values of fresh pork patties added with TPPO during storage. Meat color is the most important factor affecting consumer acceptance, purchasing decisions and satisfaction of meat products. The changes observed in color parameters (Table 4) were mainly related to the concentration of TPPO. Fresh pork patties added with TPPO had lower values $(p<0.05)$ for lightness $\left(\mathrm{CIE} \mathrm{L}^{*}\right)$ but higher $(p<0.05)$ for redness (CIE $\left.\mathrm{a}^{*}\right)$ and yellowness (CIE $\left.{ }^{*}\right)$ than the patties without tomato powder during storage. The lightness values of all tested samples were not changed, however, red-
Table 4. Changes in meat color of fresh pork patties added with TPPO during storage at $5^{\circ} \mathrm{C}$

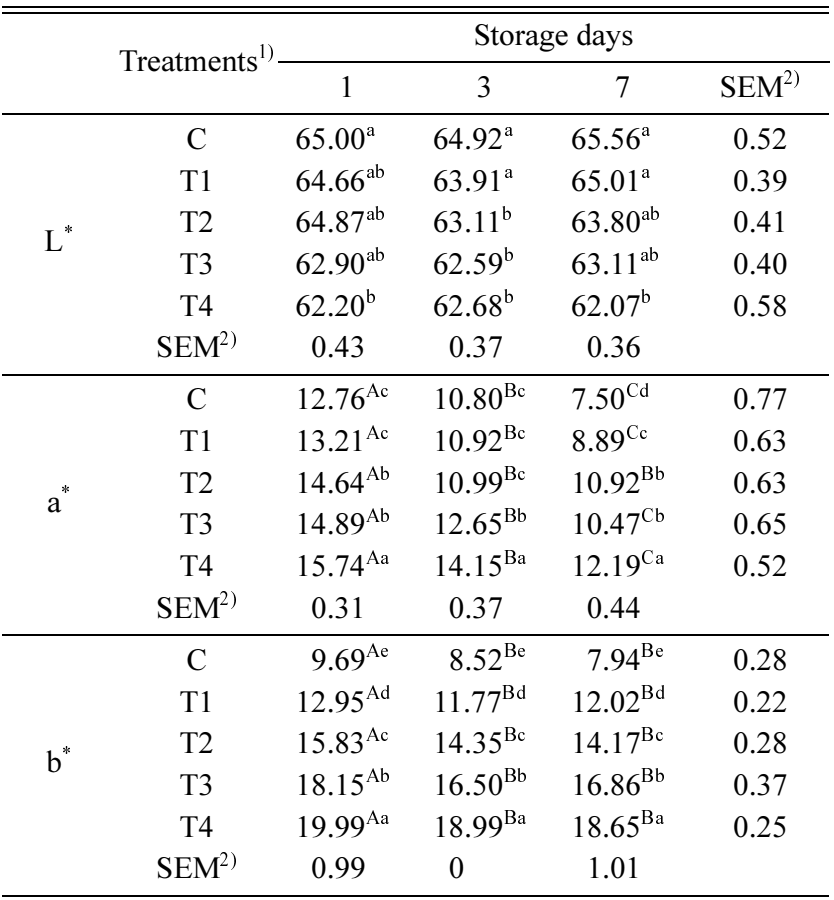

${ }^{1)}$ Treatments are the same as described in Table $1 .{ }^{2)}$ Pooled standard errors of the mean.

${ }^{\text {a-d }}$ Means with different superscripts in the same column significant differences at $p<0.05$.

${ }^{\mathrm{A}-\mathrm{C}}$ Means with different superscripts in the same row significant differences at $p<0.05$.

ness and yellowness of all samples were significantly decreased over the storage $(p<0.05)$. All treated samples added with tomato powder had lower $(p<0.05)$ lightness than the control. These products had improved red color. According to Candogan (2002), this color improving effect of tomato paste can be attributed to the pigment, lycopene, which is present in tomato paste, due to its red color and antioxidant effect. Similar results have been reported by Calvo et al. (2008). Furthermore, Østerlie and Lerfall (2005) indicated that mixing minced meat with a lycopene-containing product could reduce or replace the use of nitrite.

\section{Change of sensory evaluation}

Table 5 shows the results for sensory scores of fresh pork patties added with TPPO during storage. On day 1 and 3 of storage, the pork patties of $\mathrm{T} 3$ and $\mathrm{T} 4$ added with TPPO scored higher in color-like scores than the control, but statistical significance was not found $(p>0.05)$ in color-like scores after 7 days of storage. These high colorlike scores are maybe caused by significantly higher redness and yellowness in treated patties compared to con- 
Table 5. Changes in sensory scores ${ }^{1)}$ of non-cooked pork meat patties added with TPPO during storage at $5^{\circ} \mathrm{C}$

\begin{tabular}{|c|c|c|c|c|c|}
\hline \multirow{2}{*}{ Items } & \multirow{2}{*}{ Treatments $^{2)}$} & \multicolumn{4}{|c|}{ Storage days } \\
\hline & & 1 & 3 & 7 & SEM $^{3)}$ \\
\hline \multirow{6}{*}{ Color } & $\mathrm{C}$ & $6.33^{\mathrm{Ab}}$ & $6.00^{\mathrm{Ab}}$ & $5.33^{\mathrm{B}}$ & 0.14 \\
\hline & $\mathrm{T} 1$ & $6.33^{\mathrm{Ab}}$ & $6.25^{\mathrm{Ab}}$ & $5.17^{\mathrm{B}}$ & 0.16 \\
\hline & $\mathrm{T} 2$ & $6.83^{\mathrm{Aa}}$ & $6.25^{\mathrm{Bb}}$ & $5.17^{\mathrm{C}}$ & 0.18 \\
\hline & $\mathrm{T} 3$ & $7.17^{\mathrm{Aa}}$ & $6.75^{\mathrm{Aa}}$ & $5.67^{\mathrm{B}}$ & 0.19 \\
\hline & $\mathrm{T} 4$ & $7.17^{\mathrm{Aa}}$ & $6.75^{\mathrm{Aa}}$ & $5.50^{\mathrm{B}}$ & 0.22 \\
\hline & $\mathrm{SEM}^{3)}$ & 0.10 & 0.07 & 0.12 & \\
\hline \multirow{6}{*}{ Aroma } & $\mathrm{C}$ & $6.33^{\mathrm{Ab}}$ & $6.00^{\mathrm{Ab}}$ & $4.67^{\mathrm{B}}$ & 0.21 \\
\hline & $\mathrm{T} 1$ & $6.33^{\mathrm{Ab}}$ & $6.00^{\mathrm{Ab}}$ & $4.75^{\mathrm{B}}$ & 0.21 \\
\hline & $\mathrm{T} 2$ & $6.50^{\mathrm{Ab}}$ & $6.00^{\mathrm{Ab}}$ & $4.92^{\mathrm{B}}$ & 0.23 \\
\hline & $\mathrm{T} 3$ & $7.17^{\mathrm{Aa}}$ & $6.50^{\mathrm{Aa}}$ & $4.67^{\mathrm{B}}$ & 0.28 \\
\hline & $\mathrm{T} 4$ & $7.17^{\mathrm{Aa}}$ & $6.50^{\mathrm{Aa}}$ & $4.83^{\mathrm{B}}$ & 0.29 \\
\hline & $\mathrm{SEM}^{3)}$ & 0.1 & 0.07 & 0.16 & \\
\hline \multirow{6}{*}{ Juiciness } & $\mathrm{C}$ & $6.83^{\mathrm{Aa}}$ & $6.00^{\mathrm{B}}$ & $6.17^{\mathrm{B}}$ & 0.10 \\
\hline & $\mathrm{T} 1$ & $6.83^{\mathrm{Aa}}$ & $6.00^{\mathrm{B}}$ & $6.17^{\mathrm{B}}$ & 0.10 \\
\hline & $\mathrm{T} 2$ & $7.00^{\mathrm{Aa}}$ & $6.00^{\mathrm{C}}$ & $6.25^{\mathrm{B}}$ & 0.11 \\
\hline & $\mathrm{T} 3$ & $6.50^{\mathrm{Ab}}$ & $6.00^{\mathrm{A}}$ & $6.67^{\mathrm{B}}$ & 0.10 \\
\hline & $\mathrm{T} 4$ & $6.50^{\mathrm{Ab}}$ & $6.00^{\mathrm{B}}$ & $6.67^{\mathrm{A}}$ & 0.11 \\
\hline & $\mathrm{SEM}^{3)}$ & 0.06 & 0.00 & 0.08 & \\
\hline \multirow{6}{*}{$\begin{array}{l}\text { Overall } \\
\text { accept- } \\
\text { ability }\end{array}$} & $\mathrm{C}$ & $6.50^{\mathrm{Ab}}$ & $6.00^{\mathrm{Ab}}$ & $5.00^{\mathrm{B}}$ & 0.18 \\
\hline & $\mathrm{T} 1$ & $6.83^{\mathrm{Aab}}$ & $6.25^{\mathrm{Bb}}$ & $5.00^{\mathrm{C}}$ & 0.20 \\
\hline & $\mathrm{T} 2$ & $6.83^{\mathrm{Aab}}$ & $6.25^{\mathrm{Bb}}$ & $5.00^{\mathrm{C}}$ & 0.20 \\
\hline & $\mathrm{T} 3$ & $7.17^{\mathrm{Aa}}$ & $7.00^{\mathrm{Aa}}$ & $5.42^{\mathrm{B}}$ & 0.22 \\
\hline & $\mathrm{T} 4$ & $7.00^{\mathrm{Aa}}$ & $7.25^{\mathrm{Aa}}$ & $5.33^{\mathrm{B}}$ & 0.24 \\
\hline & $\mathrm{SEM}^{3)}$ & 0.07 & 0.10 & 0.12 & \\
\hline
\end{tabular}

${ }^{1)}$ Sensory scores were assessed on 9 point scale where $1=$ extremely bad, $9=$ extremely good.

${ }^{2)}$ Treatments are the same as described in Table 1.

${ }^{3)}$ Pooled standard errors of the mean.

${ }^{\mathrm{a}, \mathrm{b}}$ Means with different superscripts in the same column significant differences at $p<0.05$.

${ }^{\mathrm{A}-\mathrm{C}}$ Means with different superscripts in the same row significant differences at $p<0.05$.

trol (Table 4). The meat patties of T3 and T4 added with TPPO scored higher in aroma-like scores than the control at day 1 and 3 of storage, but statistical significance was not found $(p>0.05)$ in aroma scores after 7 days of storage. These high aroma-like scores in high level of tomato powder suggested that TPPO addition is an effective antioxidant in cooked meat patties (Table 3) and could be acted for the attributes against warmed over flavor in pork meat patties. These results disagreed with those of Hoe et al. (2006) who found that the $0.5 \%$ tomato powder did not change the sensory characteristics of emulsion sausages. On day 1 of storage, juiciness scores of $\mathrm{T} 3$ and T4 samples were lower than those of control, however, no significant differences were observed among the tested samples on day 3 and 7 of storage. These findings dis- agreed with those of Desmond et al. (1998) who found that the oat fiber aided in water retention, produced juicy low-fat beef patties. At day 1 and 3 of storage, the pork meat patties of $\mathrm{T} 3$ and $\mathrm{T} 4$ in overall acceptability marked higher scores compared to other samples, but statistical significance was not found after 7 days of storage $(p>0.05)$. Storage time decrease the sensory scores of color, aroma, flavor, juiciness and overall acceptance in all samples.

\section{Acknowledgments}

This study was supported by Technology Development Program for agriculture and forestry of Ministry of Agriculture and Forestry and Priority Research Centers Program through the National Research Foundation of Korea (NRF) funded by the Ministry of Education, Science and Technology, Republic of Korea.

\section{References}

1. Ahn, D. U., Jo, C., Du, M., Olson, D. G., and Nam, K. C. (2000) Quality characteristics of pork patties irradiated and stored in different packaging and storage conditions. Meat Sci. 56, 203-209.

2. Arun, K. V., Sharma, B. D., and Banerjee R. (2010) Effect of sodium chloride replacement and apple pulp inclusion on the physico-chemical, textural and sensory properties of low fat chicken nuggets. LWT - Food Sci. and Technol. 43, 715-719.

3. Calvo, M. M., Garciía, M. L., and Selgas, M. D. (2008) Dry fermented sausages enriched with lycopene from tomato peel. Meat Sci. 80, 167-172.

4. Candogan, K. (2002) The effect of tomato paste on some quality characteristics of beef patties during refrigerated storage. European Food Research and Technol. 215, 305309.

5. Choski, P. M., and Joshi, V. Y. (2007) A review on lycopene -Extraction, purification, stability and applications. Inter. J. Food Properties, 10, 289-298.

6. CIE (Commission International de l'Éclairage) (1976). Official recommendations on uniform color spaces. color difference equations and metric color terms, Suppl. No. 2. CIE Publication No. 15 Colorimetry. Paris.

7. Clinton, S. K. (1998) Lycopene chemistry, biology, and implications for human health and disease. Nutr. Rev. 56, 3551.

8. Collins, M. A., and Charles, H. P. (1987) Antimicrobial activity of carnosol and ursolic acid: Two anti-oxidant constituents of Rosmarinus officinalis L. Food Microbiol. 4, 311-315.

9. Deda, M. S., Bloukas, J. G., and Fista, G. A. (2007) Effect of tomato paste and nitrite level on processing and quality characteristics of frankfurters. Meat Sci. 76, 501-508.

10. Desmond, E., Troy, D., and Buckley, D. (1998) The effects of 
tapioca starch, oat fibre and whey protein on the physical and sensory properties of low-fat beef burgers. Lebensm. Wiss. Technol. 31, 653-657.

11. Drosinos, E. H. and Board, R. G. (1995) A survey of minced lamb packaged in modified atmospheres. Fleischwirtsch 3, 11-15.

12. Dzudie, T., Kouebou, C. P., Essia-Ngang, J. J., and Mbofung, C. M. F. (2004) Lipid sources and essential oils effects on quality and stability of beef patties. J. Food Engineering 65, 67-72.

13. Egan, H., Kirk, R. S., and Sawyer, R. (1981) Pearson's chemical analysis of foods (8th ed.), Essex: Longman scientific and Technical, UK, pp. 185-185.

14. Goula, A. M. and Adamopoulos, K. G. (2005) Stability of lycopene during spray drying of tomato pulp. Lebensm. Wiss. Technol. 38, 479-487.

15. Gould, W. V. (1992) Tomato production, processing and technology. CTI Publications, Baltimore, MD. pp. 3-254.

16. Greene, B. A. and Cumuze, T. H. (1982) Relationship between TBA numbers and inexperienced panelist's assessments of oxidised flavour in cooked beef. J. Food Sci. 47, 52-58.

17. Hoe, S. K., Park, K. H., Yang, M. R., Jeong, K. J., Kim, D. H., Choi, S. K., and Kim, I. S. (2006) Quality characteristics of low-fat emusified sausage containing tomatoes during cold storage. Korean J. Food Sci. Ani. Resour. 26, 297-305.

18. Kavanaugh, C. J., Trumbo, P. R., and Ellwood, K. C. (2007) The US food and drug administration's evidence-based review for qualified health claims: Tomatoes, lycopene and cancer. J. Natl. Cancer Inst. 99, 1074-085.

19. Kennedy, C., Buckley, D. J., and Kerry, J. P. (2005) Influence of different gas compositions on the short-term, storage stability of mother-packaged retail-ready lamb packs. Meat Sci. 69, 27-33.

20. Lin, K. W. and Lin, S. N. (2002) Effects of sodium lactate and trisodium phosphate on the physicochemical properties and shelf life of low-fat Chinese-style sausage. Meat Sci. 60, 147-154.

21. Lin, L.C., Chen, C. M., and Yen, G. C. (1995) Relationship between biogenic amine contents and quality of lean meat of Chinese-style sausage prepared from pork ham stored at different temperature. Food Sci. (Taiwan) 22, 448-460.

22. Madsen, H. L. and Bertelsen, G. (1995) Spices as antioxidants. Trends in Food Science and Technology 6, 271-277.

23. Ohashi, E., Okamoto, M., Ozawa, A., and Fugita, T. (1991) Characterization of common squid using several freshness indicators. J. Food Sci. 56, 161-163.

24. Omoni, A. O. and Aluko, R. E. (2005) The anti-carcinogenic and anti-atherogenic effects of lycopene: a review. Trends Food Sci. Tech. 16, 334-350.

25. Østerlie, M. and Lerfall, J. (2005) Lycopene from tomato products added minced meat: Effect on storage quality and colour. Food Research Inter. 38, 925-929.

26. Pearson, D. (1968) Application of chemical methods for the assessments of beef quality. J. Sci. Food Agri. 19, 366-369.

27. Razminowicz, R. H., Kreuzer, M., and Scheeder, M. R. L. (2006) Quality of retail beef from two grass-based production systems in comparison with conventional beef, Meat Sci. 73, 351-361.

28. Rhee K. S. and Ziprin, T. A. (2001) Pro-oxidative effects of $\mathrm{NaCl}$ in microbial growth-controlled and uncontrolled beef and chicken. Meat Sci. 57, 105-112.

29. Sánchez-Escalante, A., Torrescano, G., Djenane, D., BeltránJ. A., and Roncalés, P. (2003) Stabilization of colour and odour of beef patties using lycopene-rich tomato and peppers as a source of antioxidants, J. Sci. Food Agri. 83, 187-194.

30. SAS (1999) SAS/STAT Software for PC. Release 6.11, SAS Institute, Cary, NC, USA.

31. Schwarz, K., Bertelsen, G., Nissen, L. R., Gardener, P. T., Heinonen, M. I., Hopia, A., Huynh-Ba, T., Lambelet, P., McPhail, D., Skibsted, L. H., and Tijburg, L. (2001) Investigation of plant extracts for the protection of processed foods against lipid oxidation: Comparison of antioxidant assays based on radical scavenging, lipid oxidation and analysis of the principal antioxidant compounds. Eur. Food Res. Technol. 212, 319-328.

32. Su, H. P. and Lin, C. W. (1988) A survey of the storage characteristics of dried sliced pork, J. Chinese Soc. Ani. Sci. 17, 83-90.

33. Tapiero, H., Townsend, M. D., and Tew, W. D. (2004) The role of carotenoids in the prevention of human pathologies. Biomed. Pharmacother. 58, 100-110.

34. Tarladgis, B. G., Watts, B. M., Younathan, M. T., and Dugan, L. (1960) A distillation method for the quantitative determination of malonaldehyde in rancid foods. J. American Oil Chem. Soc. 37, 44-52.

35. Vergara, H. and Gallego, L. (2001) Effects of gas composition in modified-atmosphere-packaging on the meat quality of Spanish Manchega lamb, J. Sci. Food and Agri. 81, 13531357.

36. Wang, F. S. (2000) Effects of three preservative agents on the shelf life of vacuum packaged Chinese-style sausage stored at $20^{\circ}$ C. Meat Sci. 56, 67-71.

37. Yilmaz, I., Simsek, O., and Isikli, M. (2002) Fatty acid composition and quality characteristics of low-fat cooked sausage made with beef and chicken meat, tomato juice and sunflower oil. Meat Sci. 62, 253-258.

38. Zhang, S. X., Farouk, M. M., Young, O. A., Wieliczko, K. J., and Podmore, C. (2005) Functional stability of frozen normal and high pH beef. Meat Sci. 69, 765-772.

(Received 2009.4.2/Revised 1st 2010.1.26, 2nd 2010.3.30/ Accepted 2010.4.1) 